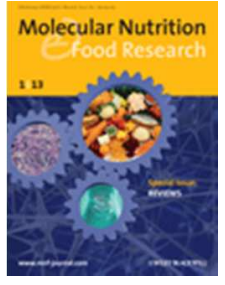

\title{
Cocoa flavonoid epicatechin protects pancreatic beta cell viability and function against oxidative stress
}

\begin{tabular}{|r|l|}
\hline Journal: & Molecular Nutrition and Food Research \\
\hline Manuscript ID: & mnfr.201300291.R2 \\
\hline Wiley - Manuscript type: & Research Article \\
\hline Complete List of Authors: & $\begin{array}{l}\text { Martín, María Angeles } \\
\text { Fernández-Millán, Elisa } \\
\text { Ramos, Sonia } \\
\text { Bravo, Laura } \\
\text { Goya, Luis }\end{array}$ \\
\hline Keywords: & $\begin{array}{l}\text { antioxidant defences, cocoa flavanols, dietary polyphenols, oxidative } \\
\text { biomarkers, type 2 diabetes mellitus }\end{array}$ \\
\hline \multicolumn{2}{|c}{} \\
\hline
\end{tabular}

SCHOLARONE

Manuscripts 


\title{
Cocoa flavonoid epicatechin protects pancreatic beta cell viability and function against oxidative stress.
}

\author{
María Ángeles Martín ${ }^{1,2}$, Elisa Fernández-Millán ${ }^{2}$, Sonia $\operatorname{Ramos}^{1}$, Laura Bravo ${ }^{1}$ and Luis Goya ${ }^{1, *}$ \\ ${ }^{1}$ Departamento de Metabolismo y Nutrición; Instituto de Ciencia y Tecnología de Alimentos y \\ Nutrición (ICTAN - CSIC). \\ ${ }^{2}$ Centro de Investigación Biomédica en red de Diabetes y Enfermedades Metabólicas Asociadas \\ (ISCIII), Madrid (Spain). \\ *Corresponding autor: Luis Goya, Departamento de Metabolismo y Nutrición, Instituto de Ciencia y \\ Tecnología de Alimentos y Nutrición (ICTAN - CSIC); José Antonio Novais, 10; 28040 Madrid, \\ Spain. Phone: +34.91.544.56.07; Fax: +34.91 .549 .36 .27$ \\ e-mail: luisgoya@ictan.csic.es
}

Keywords: antioxidant defences, cocoa flavanols, dietary polyphenols, oxidative biomarkers, type 2 diabetes mellitus 


\begin{abstract}
Scope: Diabetes mellitus is associated with reductions in glutathione, supporting the critical role of oxidative stress in its pathogenesis. Antioxidant food components such as flavonoids have a protective role against oxidative stress-induced degenerative and age-related diseases. Flavonoids such as epicatechin (EC) constitute an important part of the human diet; they can be found in green tea, grapes and cocoa and possess multiple biological activities. This study investigates the chemoprotective effect of EC against oxidative stress induced by tert-butylhydroperoxide $(t$-BOOH) on Ins1E pancreatic beta cells.
\end{abstract}

Methods and Results: Cell viability, oxidative status, phosphorilated Jun kinase (p-JNK) expression and insulin secretion were evaluated. Ins-1E cells treatment with 5-20 $\mu \mathrm{M}$ EC for 20 hours evoked no cell damage and enhanced antioxidant enzymes and insulin secretion. Addition of $50 \mu \mathrm{M} \mathrm{t}-\mathrm{BOOH}$ for 2 hours induced ROS, p-JNK and carbonyl groups and decreased GSH and insulin secretion. Pretreatment of cells with EC prevented the t-BOOH-induced ROS, carbonyl groups, p-JNK expression and cell death and recovered insulin secretion.

Conclusion: Ins-1E cells treated with EC showed a remarkable recovery of cell viability and insulin secretion damaged by $\mathrm{t}-\mathrm{BOOH}$, indicating that integrity of secreting and surviving machineries in the EC-treated cells was notably protected against the oxidative insult. 


\section{INTRODUCTION}

Beta cell failure in pancreatic islets of Langerhans is one critical metabolic disorder in the development of type 2 diabetes, thus, pharmacological administration of inducers of insulin secretion in diabetic patients has been a therapeutic strategy of preference during decades. Diabetes mellitus in experimental animals and humans is associated with reductions in antioxidants such as ascorbic acid and glutathione, suggesting the critical role of oxidative stress in its pathogenesis [1]. Antioxidant food components have a protective role against oxidative stress-induced degenerative and age-related diseases, cancer and aging $[2,3]$. Important candidates are plant flavonoids, which are naturally occurring compounds widely distributed in vegetables, fruits and beverages such as tea and wine, and possess different biological activities such as antioxidant, antiinflammatory, antiviral and anticarcinogenic $[2,4,5]$.

Flavonoids such as epicatechin (EC) constitute an important part of the human diet, they can be found in green tea, grapes and especially in cocoa [6]. Biological activities of EC are similar to those reported for other natural flavonoids and include prevention of LDL oxidation [7], scavenging of reactive oxygen species (ROS) [8], inhibition of tumour cell growth [2, 9], and anti-inflammatory activity [10]. EC possesses a well characterized in vitro antioxidant activity, and in this regard, some studies have shown that EC is an effective free radical scavenger and interferes with the oxidative/antioxidative potential of the cell $[11,12]$. Furthermore, EC regulates cell survival and proliferation in hepatic cells by induction of AKT/PI-3-kinase and ERK1/2 pathways [13]. These properties indicate that EC may have interesting health protective benefits, including beta cell protection against oxidative stress $[14,15,16]$. Despite these facts, research on the anti-diabetic properties of flavanols has mostly been focused so far on the galloyl derivatives of EC present in tea $[17,18,19]$. 
The study of the effect of dietary compounds on the regulation of antioxidant defence mechanisms and insulin secretion at the cellular/molecular level may benefit from the use of an established cell culture line such as human Ins-1E. These cells have important biological features of the pancreatic islet beta-cells including a relatively high insulin content and glucose-stimulated insulin secretion within a physiological range of glucose concentration. Therefore, these cells have been widely used as a good model of beta-cells $[18,20]$. The aim of the study was to test the potential chemo-protective effect of EC against oxidative stress chemically induced by a potent prooxidant, tert-butylhydroperoxide $(t-\mathrm{BOOH})$ in cultures of Ins-1E cells. Cell integrity, antioxidant defences, markers of oxidative damage, a cell death-related signalling pathway and insulin secretion were evaluated to assess the effect of the flavanol in the cellular response to a chemically-induced oxidative stress. 


\section{MATERIALS AND METHODS}

\section{Reagents}

(-)-Epicatechin ( $>95 \%$ of purity), $t$-BOOH, glutathione reductase (GR), reduced and oxidized glutathione, NADPH, o-phthaldehyde (OPT), dichorofluorescin (DCFH), dinitrophenylhydrazine (DNPH), bovine serum albumin (fraction V), gentamicin, penicillin G and streptomycin were purchased from Sigma Chemical (Madrid, Spain). Anti-c-Jun terminal kinases (JNKs), anti-phosphoJNK (p-JNKs) and anti-ß-actin were obtained from Cell Signaling Technology (Izasa, Madrid, Spain). Bradford reagent was from BioRad Laboratories S.A.

\section{Cell culture}

Human Ins-1E cells (a gift from Dr. Mario Vallejo, Instituto de Investigaciones Biomédicas “Alberto Sols”, CSIC, Madrid, Spain) were maintained in a humidified incubator containing $5 \%$ $\mathrm{CO}_{2}$ and $95 \%$ air at $37{ }^{\circ} \mathrm{C}$. They were grown in RPMI-1640 medium from Biowhitaker (Lonza, Madrid, Spain) with $11 \mathrm{mM}$ glucose, supplemented with $10 \%$ Biowhitaker foetal bovine serum (FBS), $1 \%$ Hepes, $1 \mathrm{mM}$ sodium pyruvate, $50 \mu \mathrm{M}$ beta-mercaptoethanol and $1 \%$ of the following antibiotics: gentamicin, penicillin and streptomycin.

\section{EC and $t-\mathrm{BOOH}$ treatment}

The different concentrations of EC, 5, 10 and $20 \mu \mathrm{M}$, were dissolved in $50 \%$ methanol and diluted in RPMI-1640 culture medium and added to the cell plates for $20 \mathrm{~h}$ to test the direct effect of EC. To induce a condition of oxidative stress, Ins-1E cells were treated with 10-100 $\mu \mathrm{M} t$-BOOH for $2 \mathrm{~h}$ and then tested for ROS production, cell viability and p-JNK protein. To evaluate the protective effect of EC against $t$-BOOH toxicity, concentrations of EC were diluted in culture medium and added to the cell plates for $20 \mathrm{~h}$; then, the medium was discarded and fresh medium containing 50 $\mu \mathrm{M}$ t-BOOH was added for $2 \mathrm{~h}$. Control cells were randomly treated with $0.5 \%$ methanol and no 
differences were detected, therefore, the results of all controls were pooled. The selection of the concentrations of EC to test is explained below (see Discussion).

\section{Evaluation of cell viability and ROS production}

Cell viability was determined by using the crystal violet assay [13]. Cells were seeded at low density $\left(10^{4}\right.$ cells per well) in 96-well plates, grown for $20 \mathrm{~h}$ and incubated with crystal violet $(0.2 \%$ in ethanol) for $20 \mathrm{~min}$. Plates were rinsed with tap water, allowed to dry, and $1 \%$ sodium dodecylsulfate (SDS) added. The absorbance of each well was measured using a microplate reader at $570 \mathrm{~nm}$. Intracellular ROS were quantified by the DCFH assay using micro plate reader [21]. After being oxidized by intracellular oxidants, DCFH will become dichorofluorescein (DCF) and emit fluorescence. For the setting of the model of oxidative stress, the DCFH probe was added for 30 min to cells cultured in 24-wells multiwell plates, then the unabsorbed probe was removed and cells were treated with different concentrations of $t$ - $\mathrm{BOOH}$ for $2 \mathrm{~h}$ and fluorescence determined; to test the protective effect, cells were treated with different doses of EC for $20 \mathrm{~h}$, then the DCFH probe was added for 30 min and they were washed with PBS before being treated with EC-free plain medium containing $50 \mu \mathrm{M} t$-BOOH for $2 \mathrm{~h}$.

\section{Determination of GSH concentration and GPx and GR activity}

The concentration of GSH and oxidized glutathione was evaluated by a fluorometric assay previously described [21]. The method takes advantage of the reaction of GSH with OPT at $\mathrm{pH} 8.0$ and fluorescence was measured at an emission wavelength of $460 \mathrm{~nm}$ and an excitation wavelength of $340 \mathrm{~nm}$. The determination of GPx activity is based on the oxidation of reduced glutathione by GPx, using $t$-BOOH as a substrate, coupled to the disappearance of NADPH by GR [21]. GR activity was determined by following the decrease in absorbance due to the oxidation of NADPH utilized in the reduction of oxidized glutathione [21]. 


\section{Determination of carbonyl groups \\ Protein oxidation of cells was measured as carbonyl groups content in supernatants according to a published method [22]. Absorbance was measured at $360 \mathrm{~nm}$ and carbonyl content was expressed as $\mathrm{nmol} / \mathrm{mg}$ protein using an extinction coefficient of $22000 \mathrm{nmol} / \mathrm{L} / \mathrm{cm}$. Protein was measured by the Bradford reagent.}

\section{Preparation of cell lysates for Western blotting}

To detect JNKs and p-JNKs, cells were lysed at $4{ }^{\circ} \mathrm{C}$ in a buffer containing $25 \mathrm{mM}$ HEPES (pH 7.5), 0.3 M NaCl, 1.5 mM MgCl $2,0.2 \mathrm{mM}$ EDTA, 0.5 mM 1,4-Dithiothreitol, 0.1\% Triton X-100, $200 \mathrm{mM}$ B-glycerolphosphate, $0.1 \quad \mathrm{mM} \quad \mathrm{Na}_{3} \mathrm{VO}_{4}, \quad 2 \mu \mathrm{g} / \mathrm{mL}$ leupeptin, and $1 \mathrm{mM}$ phenylmethylsulphonyl fluoride. The supernatants were collected, assayed for protein concentration by using the Bradford reagents, aliquoted and stored at $-80^{\circ} \mathrm{C}$ until used for Western blot analyses.

\section{JNKs and p-JNKs determination by Western Blotting}

Equal amounts of protein $(100 \mu \mathrm{g})$ were separated by SDS-PAGE and transferred to polyvinylidene difluoride filters (Protein Sequencing Membrane, BioRad). Membranes were probed with the corresponding primary antibody followed by incubation with peroxide-conjugated antirabbit Ig (GE Healthcare, Madrid, Spain). Blots were developed with the ECL system (GE Healthcare). Normalization of Western blot was ensured by $\beta$-actin and band quantification was carried out with a scanner and the Scion Image software.

\section{Determination of insulin secretion}

The insulin secretion assay was carried out in 24-well multiwell. Experiment to test the direct effect of EC on insulin secretion: Ins-1E cells were treated with EC for $20 \mathrm{~h}$, then the culture medium 
was removed and cells were placed in $\mathrm{KRB}(115 \mathrm{mM} \mathrm{NaCl}, 24 \mathrm{mM} \mathrm{NaHCO}, 5 \mathrm{mM} \mathrm{KCl}, 1 \mathrm{mM}$ $\mathrm{MgCl}_{2} 6 \mathrm{H}_{2} \mathrm{O}, 1 \mathrm{mM} \mathrm{CaCl} 22 \mathrm{H}_{2} \mathrm{O}$ ) and supplemented with $5 \mathrm{mg} / \mathrm{ml}$ BSA for a quiescent period of 90 min. Cells were subsequently incubated in KRB containing 4 (basal) or 10 (stimulating) $\mathrm{mM}$ glucose for $90 \mathrm{~min}$ and insulin secreted in supernatants was measured by an enzyme-linked immunosorbent assay (ELISA) kit (Mercodia, Uppsala, Sweden). Experiment to test effect of $t$-BOOH: Ins-1E cells were placed in KRB plus different doses of $t$-BOOH $(10-100 \mu \mathrm{M})$ for $2 \mathrm{~h}$. Experiment to test protective effect of EC: Ins-1E cells were treated with EC for $20 \mathrm{~h}$ and then placed for $2 \mathrm{~h}$ in KRB containing $10 \mathrm{mM}$ glucose and $50 \mu \mathrm{M} t$-BOOH.

\section{Statistics}

Statistical analysis of data was as follows: prior to analysis the data were tested for homogeneity of variances by the test of Levene; for multiple comparisons, one-way ANOVA was followed by a Bonferroni test when variances were homogeneous or by Tamhane test when variances were not homogeneous. The level of significance was $P<0.05$. A SPSS version 19.0 program has been used. 


\section{RESULTS}

$\underline{\text { Effect of EC on redox status of cultured Ins-1E cells }}$

In the first part of the present study, Ins-1E cells were treated with 5-20 $\mu \mathrm{M}$ EC and several parameters related to the cellular redox status and antioxidant response were evaluated. Ins-1E cells treated for 20 hours with realistic doses of EC show no increase in ROS concentration and crystal violet staining after $20 \mathrm{~h}$ (Table 1), indicating no cellular stress or damage. Similarly, treatment with 5-20 $\mu \mathrm{M}$ EC evoked no changes in the cellular store of GSH (Figure 1A). Interestingly, a significant increase of GPx and GR activity was observed after treatment of Ins-1E cells for $20 \mathrm{~h}$ with 10-20 and 5-20 $\mu \mathrm{M} \mathrm{EC}$, respectively. These results ensure that the Ins-1E cells treated with 5-20 $\mu \mathrm{M}$ EC are absolutely functional and in competent conditions to face a stressful challenge.

\section{$\underline{\text { Response of cultured Ins-1E cells to a chemically-induced oxidative stress }}$}

As other organic peroxides, $t$-BOOH can decompose to other alkoxyl and peroxyl radicals in a reaction aided by metal ions that can generate ROS [21]. Thus, 50-100 $\mu \mathrm{M} t$-BOOH for $2 \mathrm{~h}$ dosedependently enhanced ROS generation (Figure 2A) and decreased viability (Figure 2B) of Ins-1E cells. In concert, a significant increase of $\mathrm{p}$-JNKs concentration was observed in cells after $1 \mathrm{~h}$ of treatment with $50 \mu \mathrm{M} t$-BOOH (Figure 2C). Additionally, important changes in the antioxidant defence system were observed in Ins-1E cells treated with $50 \mu \mathrm{M} t$-BOOH, i.e. a dramatic decrease of GSH (Figure 3A) and an urgent and acute response of the antioxidant enzymes GPx (Figure 3B) and GR (Figure 3C) to face the challenge. Consequently, the same stressful treatment induced a significant raise in carbonyl groups proceeding from oxidative damage to proteins (Figure 4B). These results confirm a condition of oxidative stress with permanent cell damage in Ins-1E cells treated with $50 \mu \mathrm{M} t$-BOOH for $2 \mathrm{~h}$.

\section{$\underline{\text { Protective effect of EC on cultured Ins-1E cells submitted to oxidative stress }}$}

Under these extreme oxidative conditions pre-treatment of Ins-1E cell cultures with 5-20 $\mu \mathrm{M} \mathrm{EC}$ greatly prevented GSH depletion (Figure 3A) and completely recovered GPx (Figure 3B) and GR 
(Figure 3C) to pre-stress values. In line with these results, pre-treatment with 5-20 $\mu \mathrm{M} \mathrm{EC}$ significantly reduced the t-BOOH-induced ROS production (Figure 4A) and doses of 10-20 $\mu \mathrm{M} \mathrm{EC}$ recovered carbonyl group concentration (Figure 4B) to values that were similar to those observed in control unchallenged Ins-1E cells. Moreover, a significant reduction in the stress-induced protein levels of p-JNK was also achieved in Ins-1E cells pre-treated with 5-20 $\mu \mathrm{M}$ EC (Figure 5A); consequently, viability of Ins-1E cells submitted to a chemically-induced oxidative stress was fully recovered when cells were previously treated with realistic concentrations of the dietary flavanol EC (Figure 5B). These results indicate that EC treatment protects Ins-1E cell viability.

\section{Direct and protective effects of EC on insulin secretion by cultured Ins-1E cells}

Finally, glucose-stimulated insulin secretion was evaluated in order to check the direct and protective effect of EC on beta cell functionality. The three tested doses of the flavanol stimulated the glucose-stimulated insulin secretion (Figure 6A), with no changes in insulin content (data not shown) indicating an improved responsiveness to glucose of the cultured beta cells. The condition of oxidative stress induced by $50-100 \mu \mathrm{M} t$-BOOH resulted in an impressive dose-response decrease of insulin secretion by Ins-1E cells (Figure 6B), indicating a stress-induced loss of insulin functionality. Most interestingly, insulin secretion in Ins-1E cells submitted to an oxidative insult was completely restored when these cells were previously treated with 5-20 $\mu \mathrm{M}$ EC. In fact, since treatment with 20 $\mu \mathrm{M}$ EC for $20 \mathrm{~h}$ evoked a remarkable increase in insulin secretion both in basal- and stimulatingglucose conditions (Figure 6A), the insulin response in these cells was still even higher than that of untreated control Ins-1E cells (Figure 6C). These results indicate that EC treatment protects not only Ins-1E cell viability but also responsiveness of the most important Ins-1E cell function, insulin secretion. 


\section{DISCUSSION}

Pancreatic $\beta$ cell failure is one critical metabolic disorder in the development of type 2 diabetes. Decreased viability and dysfunction of $\beta$ cells would accelerate the diabetic pathogenesis associated with higher mortality. Chronic high glucose exposure would directly increase intracellular ROS generation and deteriorate mitochondrial function to uncouple ATP generation, impairing the glucose-stimulated insulin secretion $[17,18,20]$. In this study EC proved to efficiently protect integrity and functionality of insulin-secreting Ins-1E cells against a chemically-induced oxidative stress by reducing ROS over-production, recovering altered antioxidant defences, restoring insulin secreting machinery and restraining signaling pathways that promote cell death.

Although EC may have potent antioxidant effects in vitro and in vivo, both in cell culture and live animals, elevated doses of this dietary compound can also act as pro-oxidant in cell culture systems and evoke cellular damage $[23,24]$. Therefore, it is necessary to ensure that no direct cell damage is caused by reasonable concentrations of the tested antioxidant before aiming for its protective effect [2]. Concentrations of EC around $10 \mu \mathrm{M}$ were effective in most experimental conditions $[8,25,26]$. The concentration range between 5 to $20 \mu \mathrm{M}$ selected for this study is not far from realistic in order to evaluate the effect at the physiological level since steady-state concentrations around 35-50 $\mu \mathrm{M}$ of EC have been reported in rat serum $1 \mathrm{~h}$ after oral administration of $172 \mu \mathrm{M}$ of EC per $\mathrm{Kg}$ of body weight [27]. However, other authors have reported serum levels of 0.2-0.4 $\mu \mathrm{M}$ EC in humans after ingestion of $80 \mathrm{~g}$ of chocolate [28] and $25 \mathrm{~g}$ of semisweet chocolate chips [29]. In this study none of the EC concentrations selected evoked cell damage in Ins-1E cells after 20 hours. Moreover, treatment of Ins-1E in culture with physiological concentrations of the flavanol did not alter the steady-state generation of ROS and did not affect GSH concentration, maintaining the cell antioxidant store in faultless conditions to face a potential oxidative challenge.

GPx catalyzes the reduction of peroxides and is suggested to act as a barrier against hydroperoxide attack, whereas GR is implicated in recycling oxidized glutathione back to reduced 
glutathione [31]. Therefore, the function of glutathione-dependent enzymes, which participate in the defence against hydrogen peroxides and superoxides, is essential to prevent the cytotoxicity of ROS. In addition to their antioxidant capacity by directly scavenging intracellular ROS, flavanols have been recently shown to provide a parallel protection by enhancing the activity of a number of protective enzymes $[30,31]$. Nuclear factor-erythroid 2p45-related factor-2 (Nrf2) plays a central role in the induction of phase II detoxifying enzymes through its binding to the antioxidant response element (ARE). Nrf2 is sequestered in the cytoplasm as an inactive complex with its cytosolic repressor Kelch-like ECH associated protein-1 (Keap-1). Dissociation of Nrf2 from Keap-1 is crucial for its nuclear translocation, followed by binding to the DNA and activation of genes codifying for cytoprotective enzymes [32]. Indeed, we have shown that EC stimulates Nrf2 [32] and that Nrf2 induction by a cocoa procyanidin activates gene expression and protein concentration of a detoxifying enzyme [33]. In the present study we have found that the most abundant flavanol in cocoa, EC, evokes a substantial long-term increase in GPx and GR activity in Ins-1E cells. This finding should have a relevant impact on Ins-1E cells due to the low antioxidant enzymes gene expression in pancreatic tissue as compared to other tissues [1]. The results above indicate that ECtreated Ins-1E cells are in favourable conditions to face the increasing generation of ROS induced by the potent pro-oxidant $t$-BOOH and consequently to maintain cell function and escape death.

Treatment of cells with the strong pro-oxidant $t-\mathrm{BOOH}$ is an excellent model of oxidative stress in cell culture systems from different origin such as liver (HepG2) [12, 21, 31, 34, 35] and colon (Caco-2) $[33,36]$. A dose-dependent increase in ROS was observed in Ins-1E cells submitted for $2 \mathrm{~h}$ to $t$-BOOH concentrations of and over $50 \mu \mathrm{M}$, together with a significant increase of p-JNK starting at $1 \mathrm{~h}$. In parallel, antioxidant defences were also dramatically affected by the oxidative challenge, evoking a significant decrease in GSH and remarkable increase of GPx and GR activities to cope with the augmenting ROS. As a direct consequence of the altered redox status a two-fold increase in the concentration of the biomarker of oxidative damage to proteins, carbonyl groups, was found. All 
these changes resulted in a severe decrease in cell viability, indicating that doses of $t$-BOOH of and over $50 \mu \mathrm{M}$ evoked a condition of oxidative stress and cell damage in cultured Ins-1E. In this model, the $t$-BOOH-induced increase in ROS generation was significantly prevented in cultured cells pretreated with EC. These results with EC are in line with those reporting a protective effect of other flavanol, epigallocatechin gallate, in Ins-1E cells against an induced oxidative effect [37] and suggest that the ROS generated during the period of oxidative stress were more efficiently quenched in cells pre-treated with the flavanol. This could be considered as the first beneficial effect of EC on stressed Ins-1E cells.

Reduced glutathione is the main non-enzymatic antioxidant defence within the cell and plays an important role in protection against oxidative stress as a substrate in glutathione peroxidase-catalysed detoxification of organic peroxides, by reacting with free radicals and by repairing free-radicalinduced damage through electron-transfer reactions [38]. In this study, the remarkable decrease in the concentration of GSH induced by an oxidative condition in Ins-1E cells was partially prevented by pre-treatment with EC evoking a significant recovery of GSH. Since onset of diabetes mellitus in experimental animals and humans has been associated with reductions in antioxidants such as GSH $[1,39]$, the effect of EC maintaining GSH concentration above a critical threshold while facing a stressful situation represents a decisive advantage for pancreatic beta cell survival.

Induction of GPx and GR is an essential mechanism of the cell defence against oxidative insults and consequently plays a major role to overcome ROS production in the presence of $t$-BOOH (12, 21, 31, 34). An increase in GPx activity faces ROS overproduction at the expense of GSH which decrease is recovered by an enhanced GR activity. However, a rapid return of the antioxidant enzyme activities to basal values once the challenge has been surmounted will place the cell in a favorable condition to deal with a new oxidative insult. In this study, pre-treatment of Ins-1E cells with EC managed to prevent the long-lasting increase in the activities of GPx and GR induced by oxidative stress. This phenomenon, unreported to date in pancreatic beta cells, is consistent with previous 
results with quercetin [21], green tea catechins [25] and an EC-rich cocoa phenolic extract [31, 34] in other cell types.

Carbonyl groups are considered as consistent markers of oxidative damage to proteins, a crucial event in the development of cellular toxicity [22, 40]. The significant increase in the cellular concentration of carbonyl groups during oxidative stress induced by $t$-BOOH in Ins-1E cells indicated extensive damage to cellular proteins. Pre-treatment of cells with $10-20 \mu \mathrm{M} \mathrm{EC}$ significantly reduced the level of carbonyl groups demonstrating a smaller degree of protein oxidation in response to the stressful situation. The cyto-protective effect of EC on a marker of oxidative damage has previously been reported [12] and a comparable protection on oxidative markers has been observed with other dietary compounds including plant polyphenols such as tea catechins $[11,25]$, quercetin [21] and olive oil hydroxytyrosol [41] in cultured liver cells. However, the present study is the first to demonstrate a specific chemo-protective effect of EC on pancreatic beta cells.

Overproduction of ROS activates signalling cascades involving members of the mitogenactivated protein kinase (MAPK) family, such as JNKs, that play a key role in the regulation of many cellular processes including apoptosis [42-44]. Indeed, unremitting increase of p-JNK concentration leads, in many cases, to cell death [44]. We have previously shown that an enhanced p-JNK/JNK activity induced by $t$ - $\mathrm{BOOH}$ can be restrained by a cocoa phenolic extract [31], but this is the first time that a significant reduction of the stress-induced raise of p-JNK is shown by any particular flavanol in cultured pancreatic beta cells. Interestingly, EC is the major flavanol of cocoa, suggesting that most of the protecting effect of the cocoa extract both in liver and pancreatic cells might be due to EC. In agreement with this result, a protective effect of EC on hepatic HepG2 cells viability submitted to $t$-BOOH has been previously reported $[12,13,45]$. Thus, the protective mechanism of EC on Ins-1E cells submitted to an oxidative stress can be illustrated in terms of regulation of the cellular redox status, i.e. the decreased ROS production by recovered GSH levels reduces the 
necessity of peroxide detoxification through GPx and of GSH repletion from oxidized glutathione through GR. Additionally, decreased ROS level reduces oxidative damage to proteins and restraints p-JNK signalling resulting in mitigated cell death.

The search for natural compounds, preferably found in a regular diet, has received wide attention as a preventive, rather than curative, approach in order to delay the appearance of diabetic complications. A very recent report has shown that a tetrameric procyanidin evokes an increase of insulin secretion in mice [46]. In pancreatic beta cells in culture, a recent report has shown that grape seed procyanidins improve beta cell functionality [47] and Cai and Lin [17] previously showed that tea flavonol epigallocatechin gallate activates insulin signaling. The antidiabetic effect of EC was first reported by Chackravarthy and colleagues back in 1982 [14], although contradictory results were also rapidly exposed [48]. We have recently demonstrated that EC improves insulin signalling and repress glucose production via AKT and AMPK in hepatic cells [49]. Here, we report for the first time that EC undoubtedly induces glucose-stimulated insulin secretion in cultured Ins-1E cells preventing or delaying a potential beta cell dysfunction. Furthermore, EC significantly prevents the damaged insulin secretion induced by an oxidative stress. These results agree with recent reports showing that dietary EC promotes a longer lifespan in obese diabetic mice [15], and also with others showing beneficial effects of cocoa and green tea flavanols on blood glucose regulation in obese diabetic rats [16].

Although EC stability in culture medium for $20 \mathrm{~h}$ might represent an issue [50], the present results, together with previous studies $[12,13,45]$, indicate that the flavanol either binds to specific membrane sites or directly enters into the cell [unpublished data] to trigger downstream signaling pathways that modulate or facilitate translocation of nuclear factors involved in the regulation of gene expression.

Therefore, consequent with the preservation of the antioxidant defence system and decline of the deleterious p-JNK, Ins-1E cells treated with EC showed a remarkable recovery of insulin secretion 
and attenuation of cell damage after being submitted to stress. This group of results indicates that integrity of secreting and surviving machineries in the EC-treated Ins-1E cells was notably protected against the oxidative insult. Considering all data of antioxidant defences and insulin secretion, it can be concluded that $5 \mu \mathrm{M}$ EC practically normalizes cell biochemistry in spite of the oxidative challenge. This study demonstrates the chemo-protective effect of a flavanol contained in very common food stuffs such as wine, tea and in high amounts in cocoa. Therefore, EC may play a role in the protection afforded by fruits, vegetables and plant-derived beverages against diseases such as type 2 diabetes for which excess production of ROS has been implicated as a causal or contributory factor. 


\section{ACKNOWLEDGEMENTS}

This work was supported by grants AGL2010-17579 and project CSD2007-00063 from Programa

Consolider-Ingenio from the Spanish Ministry of Economy and Competitivity. The authors declare no conflict of interest. 


\section{REFERENCES}

[1] Robertson, R.P., Harmon, J.S., Pancreatic islet B-cell and oxidative stress: The importance of glutathione peroxidase. FEBS Lett. 2007, 581, 3743-48.

[2] Forester, S.C., Lambert, J.D., The role of antioxidant versus pro-oxidant of green tea polyphenols in cancer prevention. Mol. Nutr. Food Res. 2011, 55, 844-854.

[3] Nijveldt, R., van Nood, E., van Hoorn, D., Boelens, P., van Norren, K., van Leeuwen, P., Flavonoids: a review of probable mechanisms of action and potential applications. Am J Clin Nutr. 2001, 74, 418-425.

[4] Graziani, G., Argenio, G.D., Tuccillo, C., Loguercio, C., Ritieni, A., Morisco, F., Del Vecchio Blanco, C., Fogliano, V., Romano, M., Apple polyphenol extracts prevent damage to human gastric epithelial cells in vitro and to rat gastric mucosa in vivo. Gut 2005, 54, 193-200.

[5] Scalbert, A., Manach, C., Morand, C., Rémésy, C., Jiménez, L., Dietary polyphenols and the prevention of diseases. Crit. Rev. Food Sci. Nutr. 2005, 45, 287-306.

[6] Manach, C., Scalbert, A., Morand, C., Rémésy, C., Jiménez, L., Polyphenols: food sources and bioavailability. Am. J. Clin. Nutr. 2004, 79, 727-747.

[7] Steffen, Y., Jung, T., Klotz, L-O., Schewe, T., Grune, T., Sies, H., Protein modification elicited by oxidized LDL in endothelial cells: protection by epicatechin. Free. Rad. Biol. Med., 45, 955-970.

[8] Natsume, M., Osakabe, N., Yasuda, A., Baba, S., Tokunaga, T., Kondo, K., Osawa, T., Terao, J., In vitro antioxidative activity of epicatechin glucuronide metabolites present in human and rat plasma. Free Rad. Res. 2004, 38, 1341-8.

[9] Jourdain, C., Tenca, G., Deguercy, A., Troplin, P., Poelman, D., In-vitro effects of polyphenols from cocoa and beta sitosterol on the growth of human prostate cancer and normal cells. Eur. J. Cancer Prev. 2006, 4, 353-61. 
[10] Ramiro, E., Franch, A., Castellote, C., Perez-Cano, F., Permanyer, J., Izquierdo-Pulido, M., Castell, M., Flavonoids from Theobroma cacao down-regulate inflammatory mediators. J. Agric. Food Chem. 2005, 53, 8506-11.

[11] Chen, L., Yang, X., Jiao, H, Zhao, B., Tea catechins protect against lead-induced cytotoxicity, lipid peroxidation, and membrane fluidity in HepG2 cells. Toxicological Sci. 2002, 69, 149-156.

[12] Martín, M.A., Ramos, S., Mateos, R., Izquierdo-Pulido, M., Bravo, L. and Goya, L., Protection of human HepG2 cells against oxidative stress induced by the flavonoid epicatechin". Phytotherapy Res. 2010, 24, 503-509.

[13] Granado-Serrano, A.B., Martín, M.A., Izquierdo-Pulido, M., Goya, L., Bravo, L., Ramos, S., Molecular mechanisms of (-)-epicatechin and chlorogenic acid on the regulation of the apoptotic and survival/proliferation pathways in a human hepatoma cell line (HepG2). J. Agric. Food Chem. 2007, $55,2020-2027$.

[14] Chakravarthy, B.K., Gupta, S., Gode, K.D., Functional beta cell regeneration in the islets of pancreas in alloxan induced diabetic rats by (-)-epicatechin. Life Sci. 1982, 31, 2693-2697.

[15] Si, H., Fu, Z., Babu, P.V.A., Zhen, W., LeRoith, T., Meaney, M.P., Voelker, K.A., Jia, Z., Grange, R.W., Liu, D., Dietary Epicatechin Promotes Survival of Obese Diabetic Mice and Drosophila melanogaster. J. Nutr. 2011, 141, 1095-100.

[16] Stote, K.S., Clevidence, B.A., Novotny, J.A., Henderson, T., Radecki, S.V., Baer, D.J., Effect of cocoa and green tea on biomarkers of glucose regulation, oxidative stress, inflammation and hemostasis in obese adults at risk for insulin resistance. Eur. J. Clin. Nutr., 2012, 66, 1153-9.

[17] Cai, E.P., Lin, J.K., Epigallocatechin gallate (EGCG) and rutin suppresss the glucotoxicity through activating IRS2 and AMPK signalling in rat pancreatic beta cells. J. Agric. Food Chem. 2009, 57, 9817-27.

[18] Lin, N., Zhang, H., Su, Q., Advanced glycation end-products induce injury to pancreatic beta cells through oxidative stress. Diabetes Metab. 2012, 38, 250-7. 
[19] Williamson, G., Possible effects of dietary polyphenols on sugar absorption and digestion. Mol. Nutr. Food Res. 2013, 57, 48-57.

[20] Kim, M.K., Jung, H.S., Yoon, C.S., Ko, J.H., Chun, H.J., Kim, T.K., Kwon, M.J., Lee, S.H., Koh, K.S., Rhee, B.D., Park, J.H., EGCG and quercetin protected INS-1 cells in oxidative stress via different mechanisms. Front. Biosci. 2010, 2, 810-7.

[21] Alía, M., Ramos, S., Mateos, R., Bravo, L., Goya, L., Quercetin protects human hepatoma cell line (HepG2) against oxidative stress induced by tertbutyl hydroperoxide. Toxicol. Appl. Pharmacol. 2006, 212, 110-118.

[22] Granado-Serrano, A.B., Martín, M.A., Bravo, L, Goya, L., Ramos, S., A diet rich in cocoa attenuates $N$-nitrosodiethylamine-induced liver injury in rats. Food Chem. Toxicol. 2009, 47, 24992506.

[23] Azam, S., Hadi, N., Khan, N.U., Hadi, S.M., Prooxidant property of green tea polyphenols epicatechin and epigallocatechin-3-gallate: implications for anticancer properties. Toxicol. In vitro 2004, 18, 555-561.

[24] Lapidot, T., Walter, M., Kanner, J., Antioxidant and prooxidant effects of phenolics on pancreatic beta-cells in vitro. J. Agric. Food Chem. 2002, 50, 7220-25.

[25] Murakami, C., Hirakawa, Y., Inui, H., Nakano, Y., Yoshida, H., Effect of tea catechins on cellular lipid peroxidation and cytotoxicity in HepG2 cells. Biosci. Biotechnol. Biochem. 2002, 66, 1559-62.

[26] Zhu, Q.Y., Holt, R.R., Lazarus, S.A., Orozco, T.J., Keen, C.L., Inhibitory effect of cocoa flavanols and procyanidin oligomers on free radical-induced erythrocyte hemolysis. Experiment. Biol. Med. 2002, 227, 321-329.

[27] Baba, S., Osakabe, N., Natsume, N., Muto, Y., Takizawa, T., Terao, J., In vivo comparison of the bioavailability of catechin, epicatechin and their mixture in orally administered rats. J. Nutr. 2001, 131, 2885-2891. 
[28] Rein, D., Lotito, S., Holt, R.R., Keen, C.L., Schmitz, H.H., Fraga, C.G., Epicatechin in human plasma: in vivo determination and effect of chocolate consumption on plasma oxidation status. $J$. Nutr. 2000, 130, 2109-2114.

[29] Holt, R.R., Schramm, D.D., Keen, C.L., Lazarus, S.A., Schmitz, H.H., Chocolate consumption and platelet function. J. Am. Med. Assoc. 2002, 287, 2212-2213.

[30] Masella, R., Di Benedetto, R., Varì, R., Filesi, C., Giovannini, C., Novel mechanisms of natural antioxidant compounds in biological systems: involvement of glutathione and glutathione-related enzymes. J. Nutr. Biochem. 2005, 16, 577-86.

[31] Martín, M.A., Granado-Serrano, A.B., Ramos, S., Izquierdo-Pulido, M., Bravo, L., Goya, L., Cocoa flavonoids up-regulate antioxidant enzymes activity via ERK1/2 pathway to protect against oxidative stress-induced apoptosis in HepG2 cells. J. Nutr. Biochem. 2010, 21, 196-205.

[32] Granado-Serrano, A.B., Martín, M.A., Haegeman, G., Goya, L., Bravo, L., Ramos, S., Epicatechin induces NF- $\mathrm{B}$, activator protein-1 (AP-1) and nuclear transcription factor erythroid 2p45-related (Nrf2) via phosphatidylinositol-3-kiinase/protein kinase B (PI3K/AKT) and extracellular regulated kinase (ERK) signalling in HepG2 cells. Brit. J. Nutr. 2010, 103, 168-179.

[33] Rodríguez-Ramiro, I., Ramos, S., Bravo, L., Goya, L., Martín, M.A., Procyanidin B2 induces Nrf2 translocation and glutathion-S-transferase P1 expresión and via ERKs and p38-MAPK pathways and protect human colonic cells against oxidative stress. Eur. J. Nutr. 2012, 51, 881-92.

[34] Martín, M.A., Ramos, S., Mateos, R., Granado-Serrano, A.B., Izquierdo-Pulido, M., Bravo, L. and Goya, L., Protection of human HepG2 cells against oxidative stress by cocoa phenolic extract. $J$. Agric. Food Chem. 2008, 56, 7765-72.

[35] Lima, C.F., Fernandes-Ferreira, M., Pereira-Wilson, C., Phenolic compounds protect HepG2 cells from oxidative damage: relevance of glutathione levels. Life Sci. 2006, 79, 2056-68.

[36] Rodríguez-Ramiro, I., Martín, M.A., Ramos, S., Bravo, L., Goya, L., Comparative effects of dietary flavanols on antioxidant defences and their response to oxidant-induced stress on Caco 2 cells. Eur. J. Nutr. 2011, 50, 313-22. 
[37] Kim, M.K., Jung, H.S., Yoon, C.S., Ko, J.H., Chun, H.J., Kim, T.K., Kwon, M.J., Lee, S.H., Koh, K.S., Rhee, B.D., Park, J.H., EGCG and quercetin protected INS-1 cells in oxidative stress via different mechanisms. Front Biosci. 2010, 2, 810-7.

[38] Scharf, G., Prustomersky, S., Knasmuller, S., Schulte-Hermann, R., Huber, W.W., Enhancement of glutathione and g-glutamylcysteine synthetase, the rate limiting enzyme of glutathione synthesis, by chemoprotective plant-derived food and beverage components in the human hepatoma cell line HepG2. Nutr. Cancer 2003, 45, 74-83.

[39] Tomaru, M., Takano, H., Osakabe, N., Yasuda, A., Inoue, K., Yanagisawa R., Ohwatari, T., Uematsu, H., Dietary supplementation with cacao liquor proanthocyanidins prevents elevation of blood glucose levels in diabetic obese mice. Nutrition. 2007, 4, 351-5.

[40] Mateos, R., Bravo, L., Chromatographic and electrophoretic methods for the analysis of biomarkers of oxidative damage to macromolecules (DNA, lipids, and proteins). J. Sep. Sci. 2007, $30,175-191$.

[41] Goya, L., Mateos, R., Bravo, L., Effect of the olive oil phenol hydroxytyrosol on human hepatoma HepG2 cells. Protection against oxidative stress induced by tert-butylhydroperoxide. Eur. J. Nutr. 2007, 46, 70-78.

[42] Li, H.L., Huang, Y., Zhang, C.N., Liu, G., Wei, Y.S., Wang, A.B., Liu, Y.Q., Hui, R.T., Wei, C., Williams, G.M., Liu, D.P., Liang, C.C., Epigallocathechin-3 gallate inhibits cardiac hypertrophy through blocking reactive oxidative species-dependent and -independent signal pathways. Free Radic. Biol. Med. 2006, 40, 1756-75.

[43] Valko, M., Leibfritz, D., Moncol, J., Cronin, M.T., Mazur, M., Telser, J., Free radicals and antioxidants in normal physiological functions and human disease. Int. J. Biochem. Cell Biol. 2007, $39,44-84$.

[44] Ramos, S. Cancer chemoprevention and chemotherapy: dietary polyphenols and signalling pathways. Mol. Nutr. Food Res. 2008, 52, 507-26. 
[45] Granado-Serrano, A.B., Martín, M.A., Goya, L., Bravo, L., Ramos, S., Time-course regulation of survival pathways by epicatechin on HepG2 cells. J. Nutr. Biochem. 2009, 20, 115-124.

[46] Yamashita, Y., Okabe, M., Natsume, M., Ashida, H., Cinnamtannin A2, a tetrameric procyanidin, increases GLP-1 and insulin secretion in mice. Biosci. Biotechnol. Biochem. 2013, 77, 888-91.

[47] Castell-Auví, A., Cedó, L., Pallarès, V., Blay, M., Pinent, M., Ardévol, A., Grape seed procyanidins improve $\beta$-cell functionality under lipotoxic conditions due to their lipid-lowering effect. J. Nutr. Biochem. 2013, 24, 948-53.

[48] Sheehan, E.W., Stiff, D.D., Duah, F., Slatkin, D.J., Schiff, P.L. Jr, Zemaitis, M.A., The lack of effectiveness of (-)-epicatechin against alloxan induced diabetes in Wistar rats. Life Sci. 1983, 33, 593-7.

[49] Cordero-Herrera, I., Martín, M.A., Bravo, L., Goya, L., Ramos, S., Cocoa flavonoids improve insulin signalling and repress glucose production via AKT and AMPK in HepG2 cells. Mol. Nutr. Food Res. 2013, 57, 975-85.

[50] Zhu, Q.Y., Hammerstone, J.F., Lazarus, S.A., Schmitz, H.H., Keen, C.L., Stabilizing effect of ascorbic acid on flavan-3-ols and dimeric procyanidins from cocoa. J. Agric. Food Chem. 2003, 51, 828-33. 


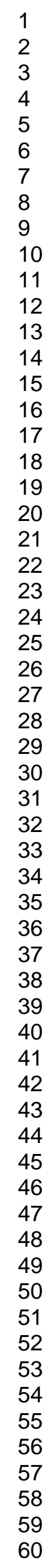




\section{LEGENDS TO FIGURES}

Figure 1.- Effect of EC on GSH concentration and GPx and GR activity. Ins-1E cells were treated with 5-20 $\mu \mathrm{M}$ EC for $20 \mathrm{~h}$ and then washed and collected to test for fluorescent analysis of GSH (A) and spectrophotometric assay of GPx (B) and GR (C). Values are means of 5 different samples per condition. Different letters indicate statistically significant differences $(P<0.05)$ among different groups.

Figure 2.- Effect of $t$-BOOH on ROS production, cell viability and p-JNK protein concentration. Ins1E cells were treated with $10-100 \mu \mathrm{M} t-\mathrm{BOOH}$ for $2 \mathrm{~h}$ and then tested for ROS levels by DCFH probe (A), cell viability by crystal violet assay (B) and p-JNK protein values by western blot (C). Within panel C, left picture shows a representative western blot for $\mathrm{p}-\mathrm{JNK}$ and right plot shows the densitometric analysis of three different blots. Values of ROS and crystal violet are means $\pm \mathrm{SD}$ of 6 8 data and those of p-JNK are means of three different assays. Different letters indicate statistically significant differences $(P<0.05)$ among different groups within the same plot.

Figure 3.- Protective effect of EC on GSH concentration and GPx and GR activity. Ins-1E cells were treated with 5-20 $\mu \mathrm{M} \mathrm{EC}$ for $20 \mathrm{~h}$ and then washed and submitted to $50 \mu \mathrm{M} t$-BOOH for $2 \mathrm{~h}$ prior to assay for GSH, GPx and GR to test for the protective effect. Values are means $\pm \mathrm{SD}, \mathrm{n}=5$. Different letters indicate statistically significant differences $(P<0.05)$ among different groups.

Figure 4.- Protective effect of EC on intracellular ROS generation and carbonyl group production. Ins- $1 \mathrm{E}$ cells were treated with 5-20 $\mu \mathrm{M} \mathrm{EC}$ for $20 \mathrm{~h}$ and then treated with $50 \mu \mathrm{M}$ t-BOOH for $2 \mathrm{~h}$ and ROS (A) and carbonyl groups (B) were determined. Values are means \pm SD of 7-8 different samples per condition. Different letters upon symbols indicate statistically different data $(P<0.05)$. 
Figure 5.- Protective effect of EC on p-JNK protein levels and cell viability. Ins-1E cells were treated with 5-20 $\mu \mathrm{M}$ EC for $20 \mathrm{~h}$, then the cultures were washed and $50 \mu \mathrm{M}$ t-BOOH was added to all cells except controls for $2 \mathrm{~h}$. (A) cell homogenates were assayed for p-JNK and total JNK by western blot; a representative blot is depicted in the upper side of panel A and densitometric results from 3 different assays are shown in the lower plot of panel A. (B) Data of cell viability by crystal violet assay are means $\pm \mathrm{SD}$ of 7-8 different samples per condition. Different letters upon symbols indicate statistically different data $(P<0.05)$.

Figure 6.- Direct effect of EC and t-BOOH and protective effect of EC on insulin secretion in Ins-1E cells. (A) Cells were treated with 5-20 $\mu \mathrm{M}$ EC for $20 \mathrm{~h}$ and then incubated in KRB containing 4 or 10 $\mathrm{mM}$ glucose for $90 \mathrm{~min}$ and insulin secreted in supernatants was measured. (B) Cells were placed in KRB plus different doses of t-BOOH (10-100 $\mu \mathrm{M})$ for $2 \mathrm{~h}$ and insulin secreted was determined. (C) Cells were treated with 5-20 $\mu \mathrm{M}$ EC for $20 \mathrm{~h}$ and then placed in KRB containing $10 \mathrm{mM}$ glucose and $50 \mu \mathrm{M}$ t-BOOH for $2 \mathrm{~h}$ before insulin secreted was evaluated. Values are means \pm SD of $4-5$ different samples per condition. Different letters indicate statistically significant differences $(P<$ 0.05) among different groups. 
Figure 1

A)

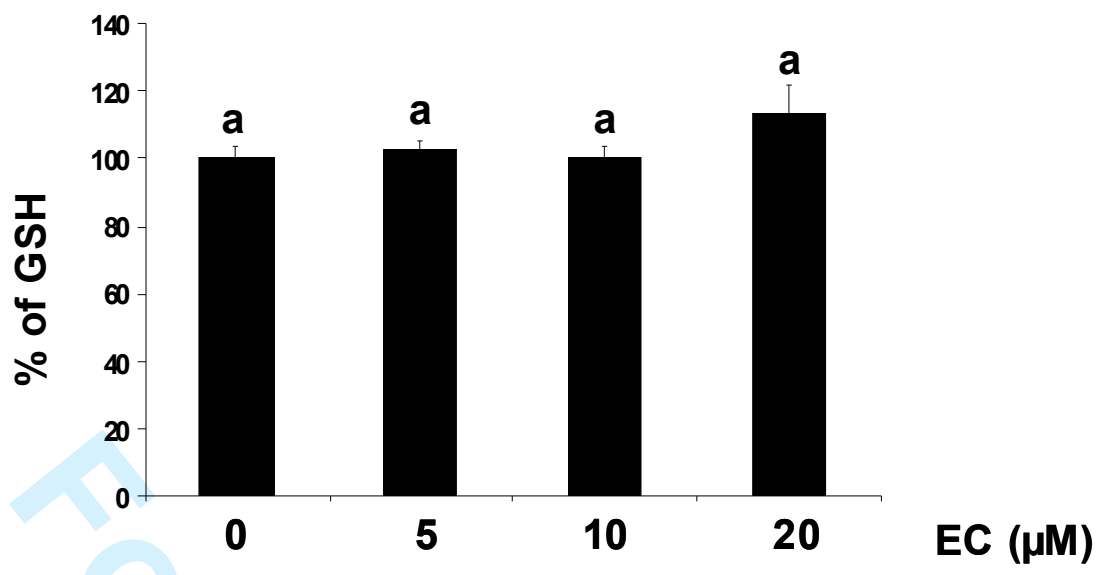

B)

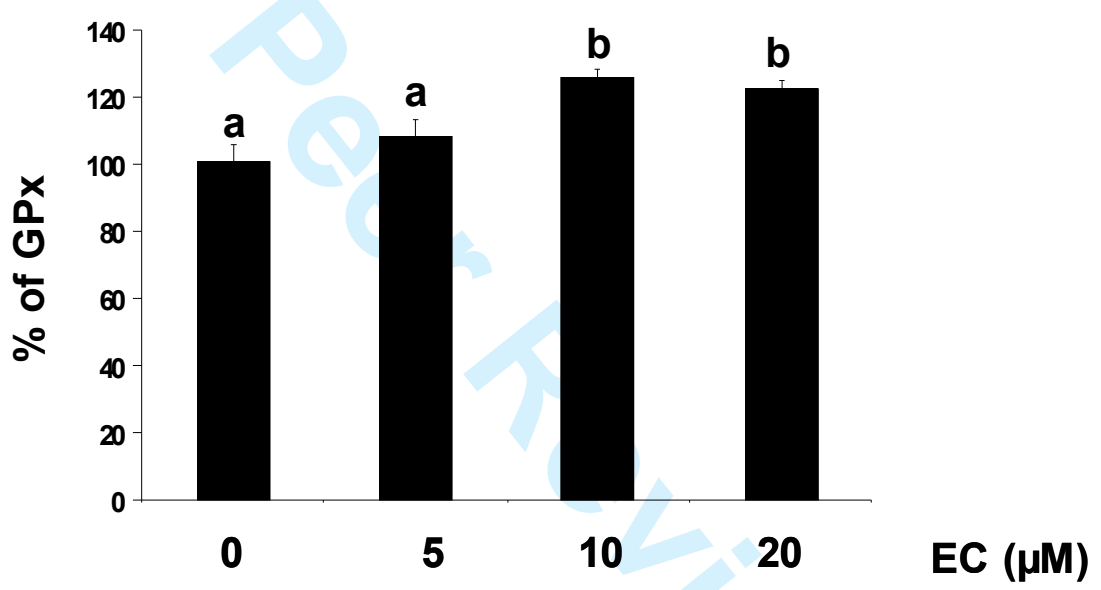

C)

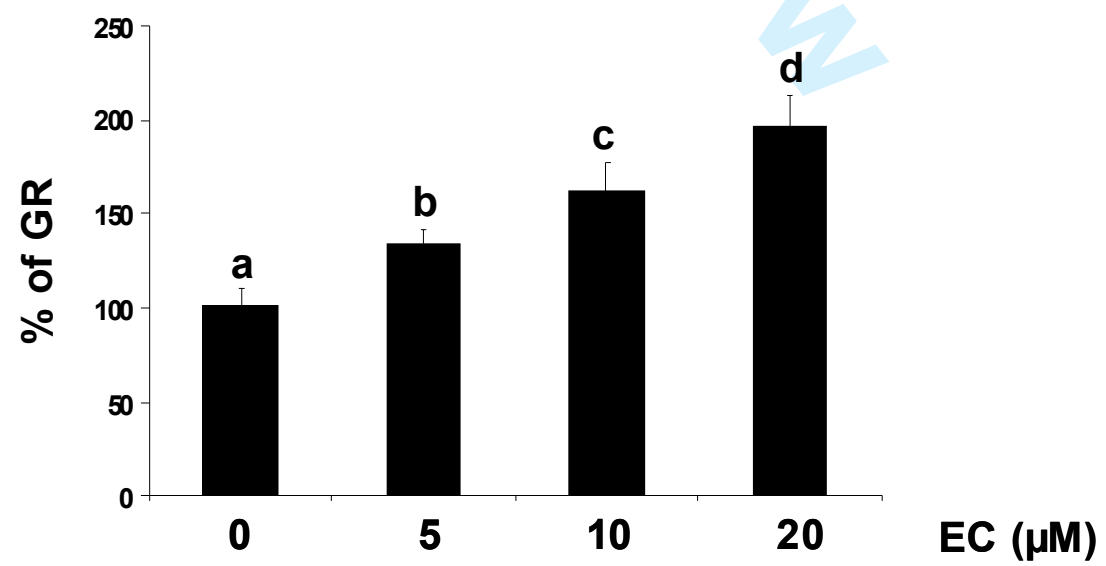


Figure 2

A)

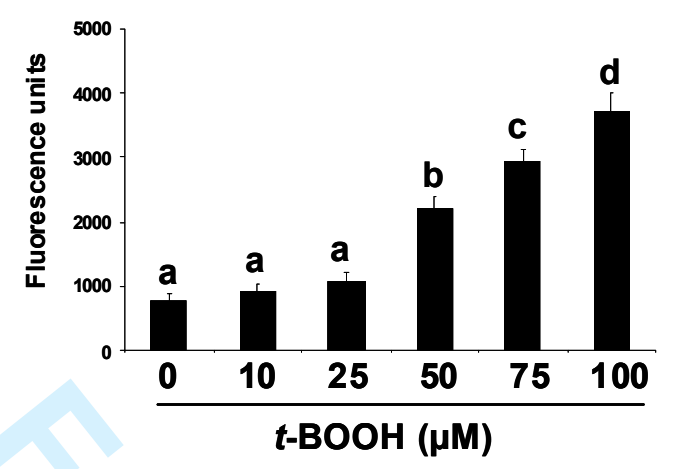

B)

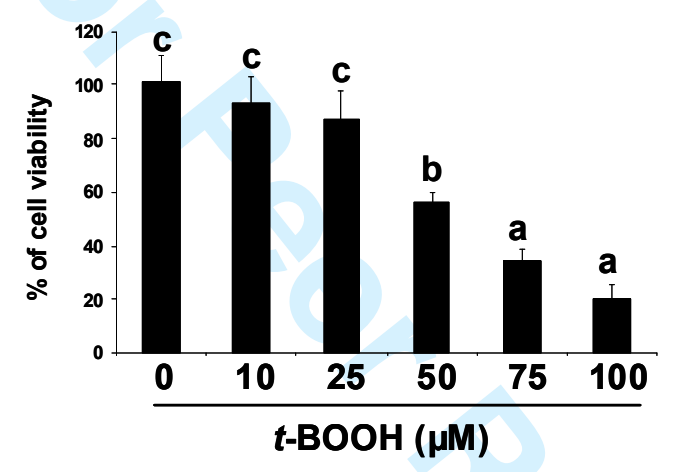

C)
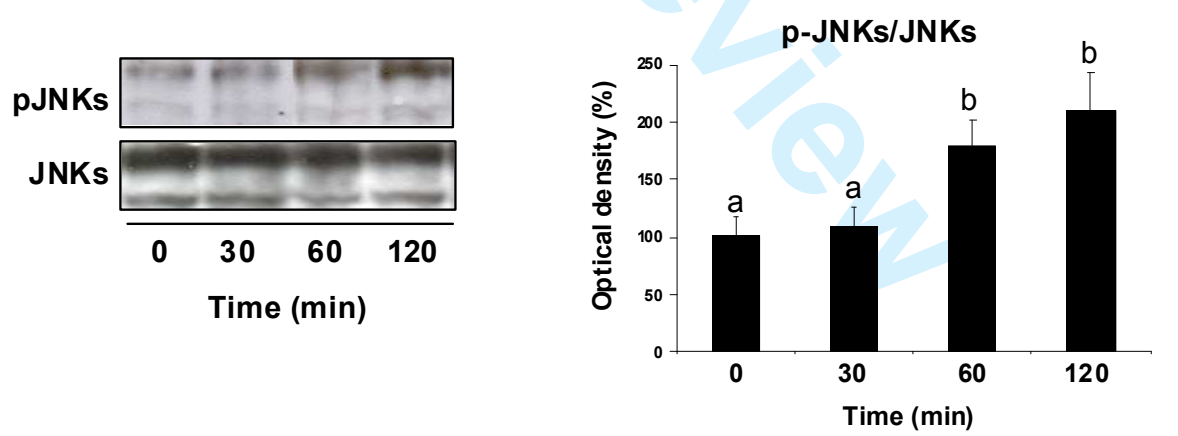
Figure 3

A)

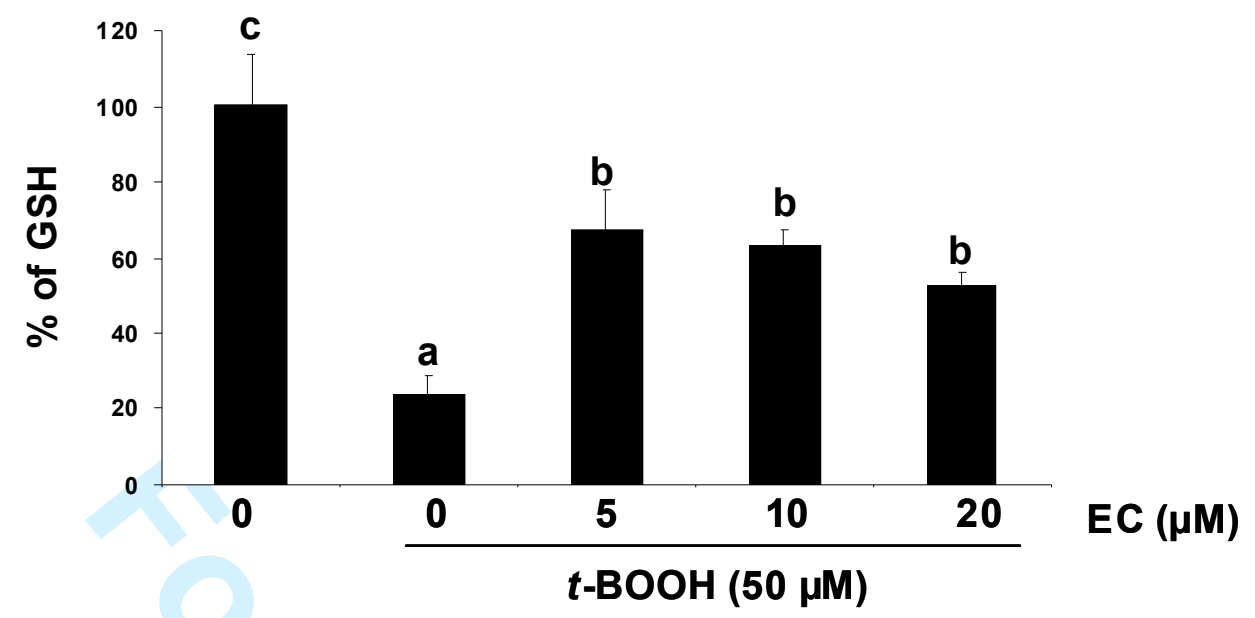

B)

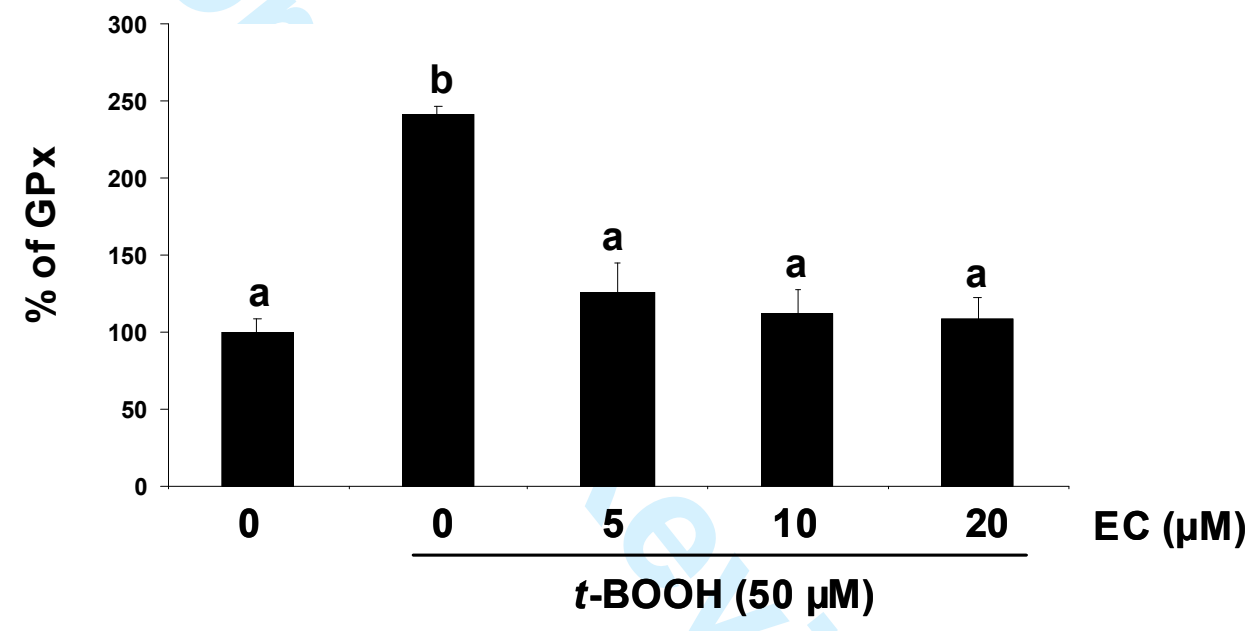

C)

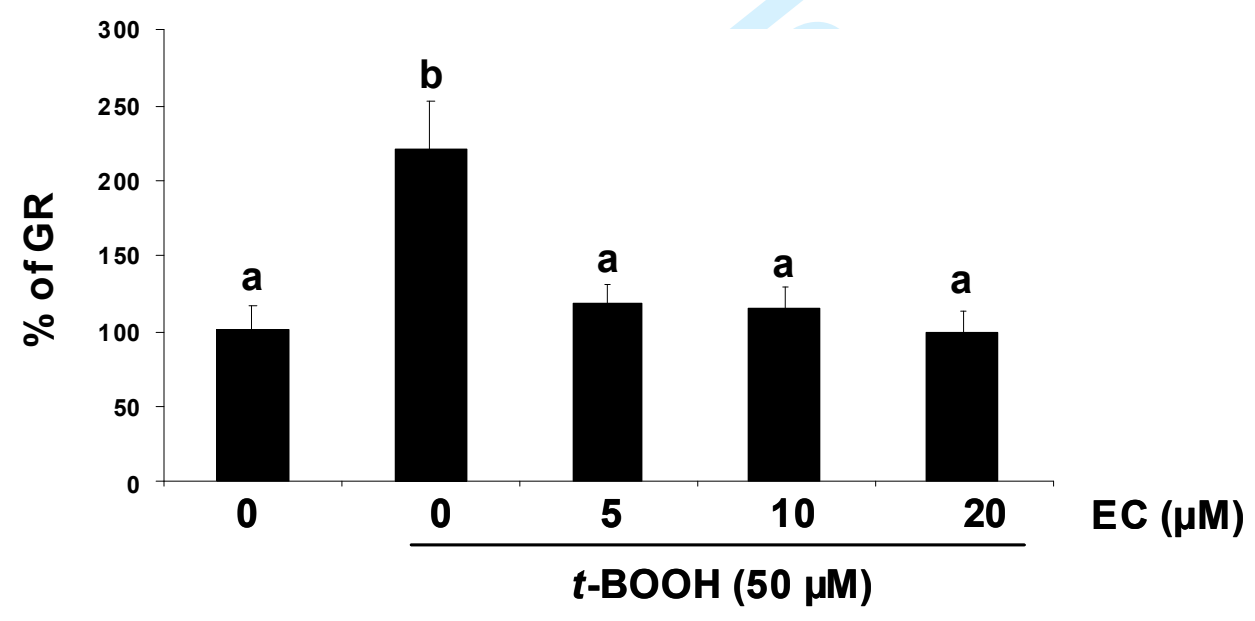


Figure 4

A)

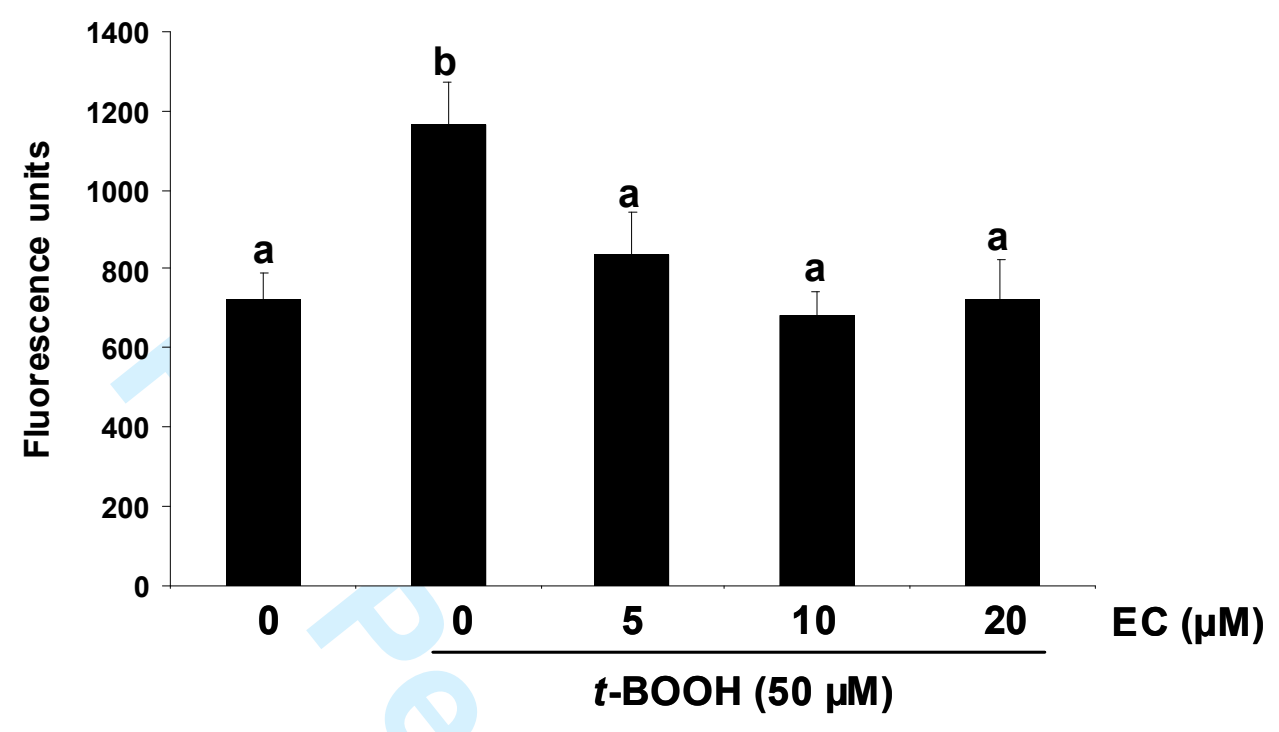

B)

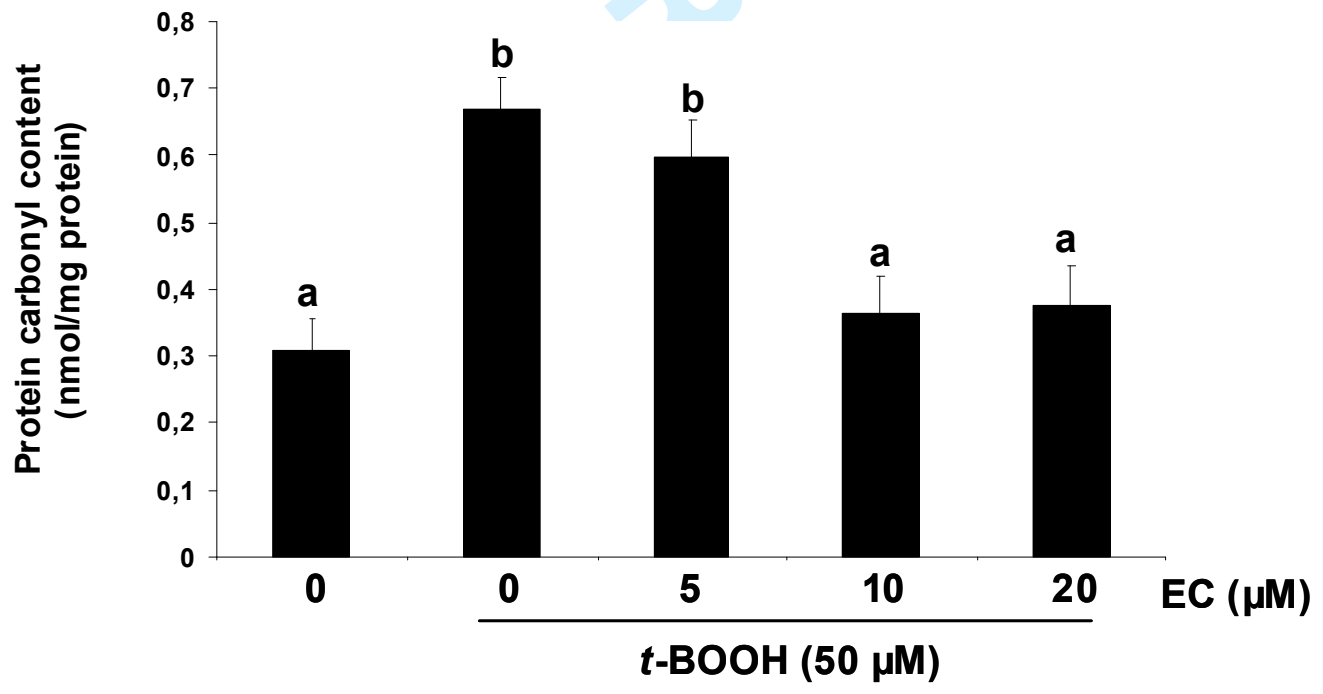


Figure 5

A)
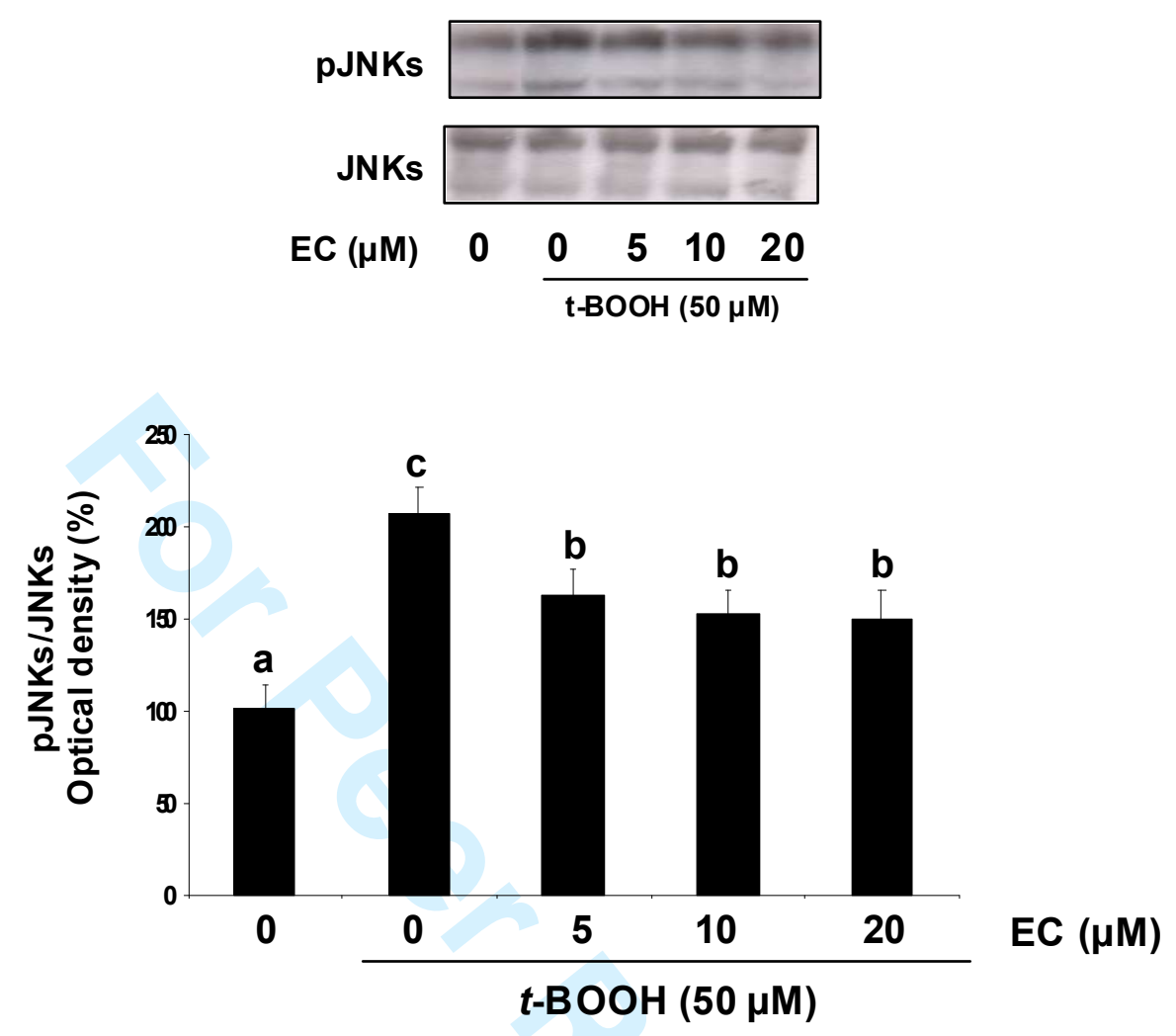

B)

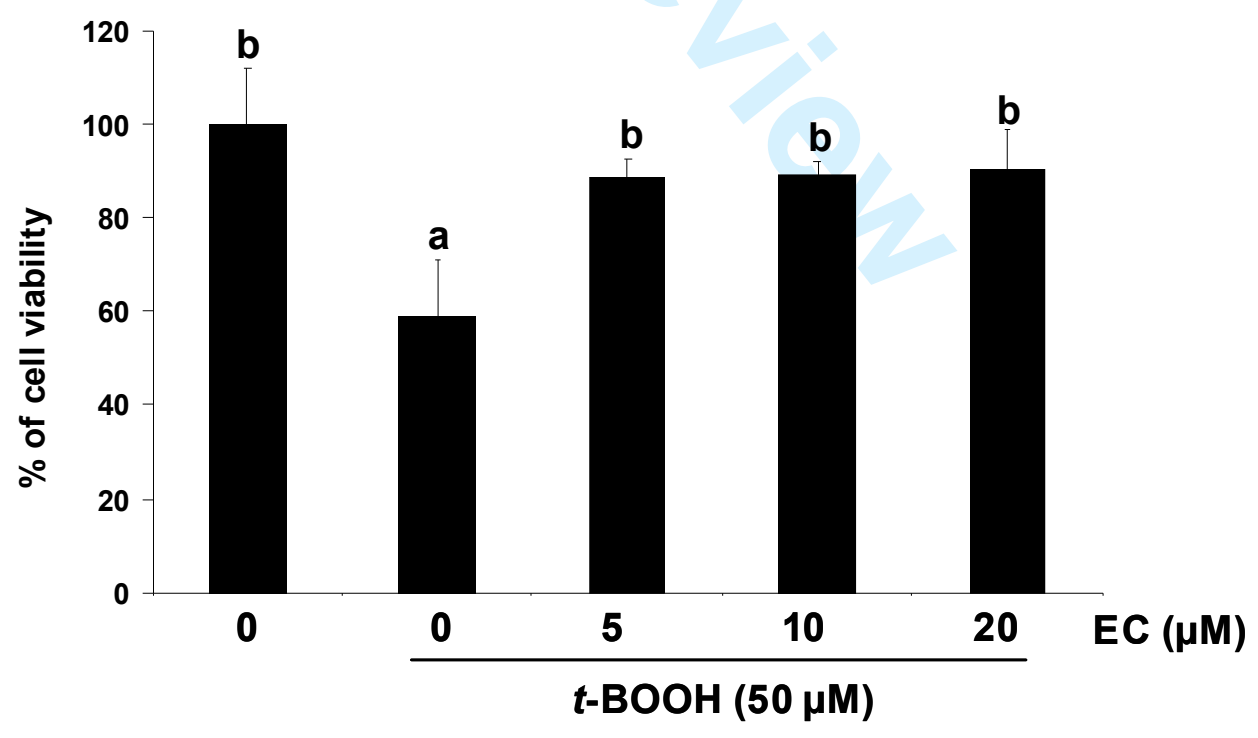


Figure 6

A)

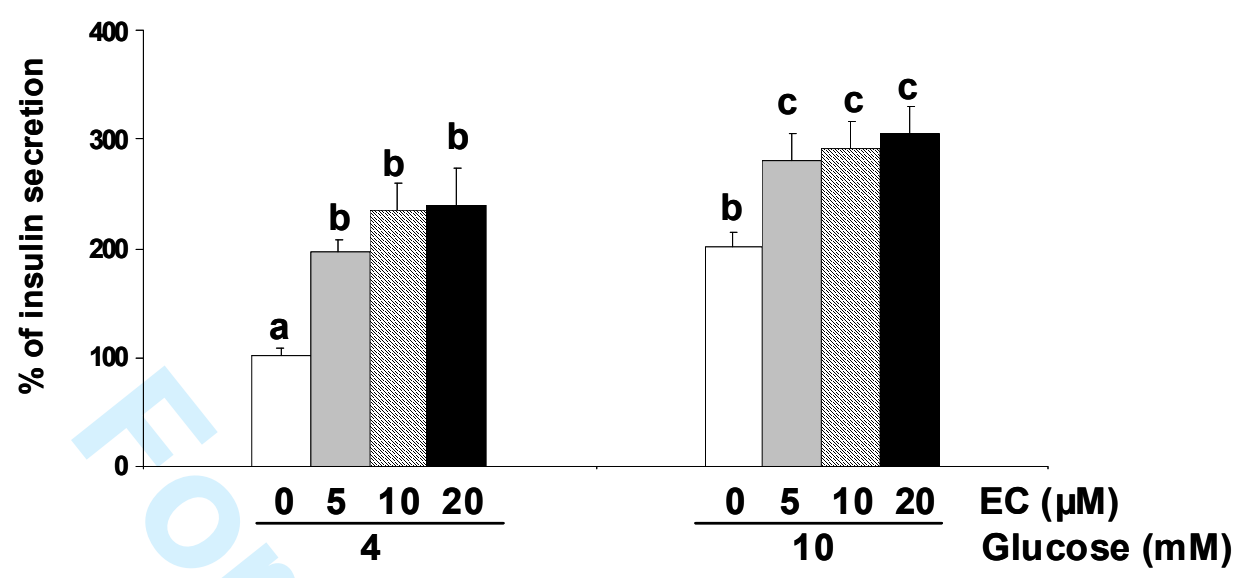

B)

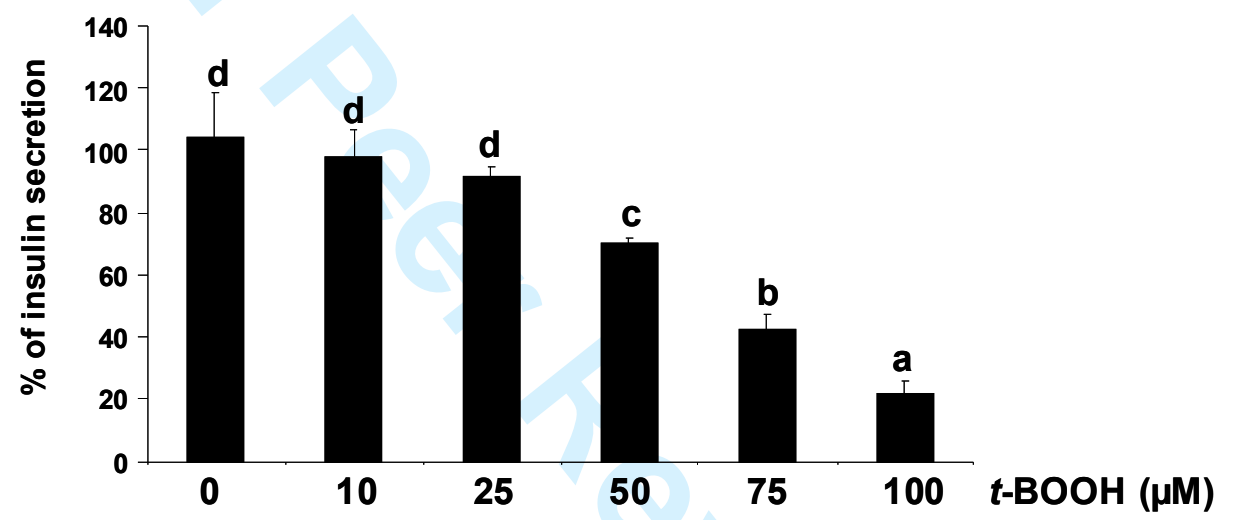

C)

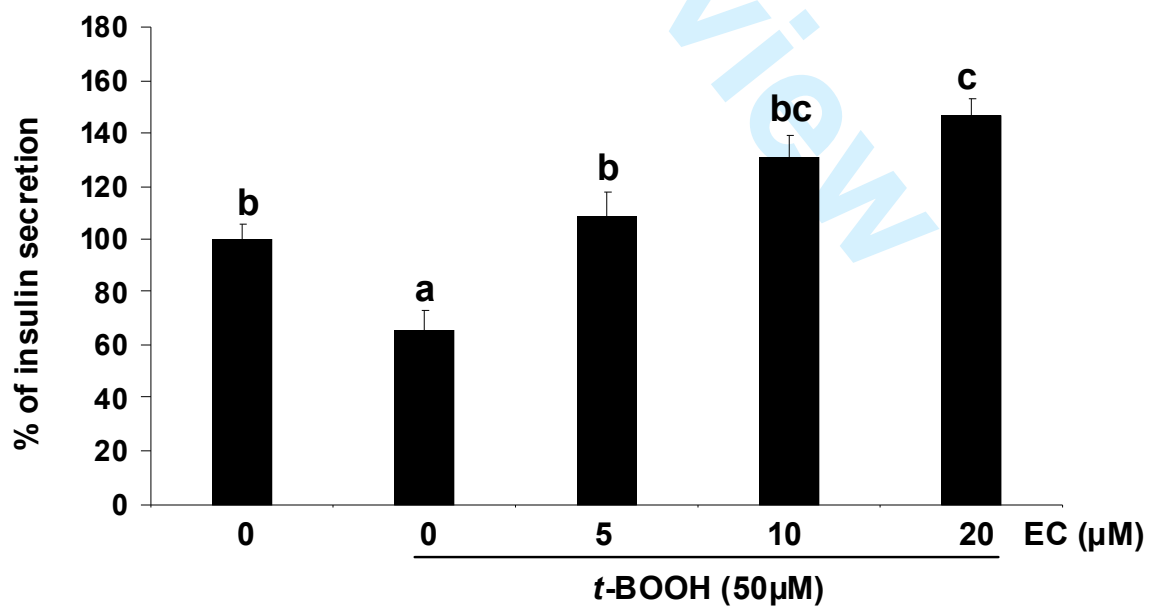


Table 1.- Effect of 20 hours treatment with noted concentrations of EC on cell viability and intracellular ROS generation in pancreatic INS-1E cells.

\begin{tabular}{|c|c|c|c|}
\hline & & $\%$ Cell Viability & $\begin{array}{c}\% \text { ROS } \\
\text { (Fluorescence Units) }\end{array}$ \\
\hline$C$ & & $100,1 \pm 9,5^{\mathbf{a}}$ & $100,9 \pm 7,2^{\mathbf{a}}$ \\
\hline \multirow[t]{3}{*}{$E C$} & $5 \mu M$ & $97,9 \pm 6,4^{\mathrm{a}}$ & $103,6 \pm 9,3^{\mathbf{a}}$ \\
\hline & $10 \mu M$ & $98,0 \pm 9,6^{\mathbf{a}}$ & $105,3 \pm 6,1^{\mathbf{a}}$ \\
\hline & $20 \mu M$ & $101,0 \pm 8,7^{\mathbf{a}}$ & $103,8 \pm 9,6^{\mathbf{a}}$ \\
\hline
\end{tabular}

